\title{
Pragmatic and Universal Dimension of Socialisation. Perspective of Experiences of Prisoners - Citizens of Former USSR
}

\author{
Arkadiusz Urbanek \\ University of Wroclaw, Department of Historical and Pedagogical Sciences, Institute of Pedagogy, \\ ul. J. W. Dawida 1, 50-527 Wrocław, Poland, urbanek.akradiusz@vp.pl
}

\begin{abstract}
The basic aim of these reflections is to answer the question what is the retrospective picture of socialisation processes, as seen by the researched prisoners. Such general issue combines the interpretation of socialisation, perception of its overt and hidden meaning, as well as personal reflection regarding own experiences. Taking the above into account, the author attempted to present individual, biographical experiences of a very specific group, i.e. citizens of Russia and former Soviet republics, whose period of childhood proceeded in the 1970s and 1980s. The interviews were conducted among a group of prisoners currently serving sentence in Polish prisons, but socialised during the period of Soviet Union. The methodological procedure followed qualitative research paradigm, oriented at reconstruction of experiences from the childhood and youth.
\end{abstract}

Keywords: socialisation, personal experiences, biography, values and socialization experiences.

Introduction. Selection of the respondent group was intentional and justified, as first of all, these persons were socialised in a social reality that does not exist anymore. Secondly, they serve sentences in Polish prisons and their life situation involves facing decision on own further choices. Previous life experiences made them criminal offenders, but simultaneously they have to decide on their future after completing the sentence. Regardless of the fact whether they will come back to the criminal life or not, they all ponder over their own possibilities referring at the same time to their potentials, gathered during the period of socialisation. Retrospection that can be carried out by the respondents in order 
to asses usefulness and aims of socialisation from the respective of time constitutes a unique research phenomenon.

Carrying out the research in the group of prisoners, former USSR citizens, contributed to the accomplishment of indirect goals. Recalling personal experiences must take into consideration specific social and institutional context of the socialisation, hence the personal experiences present wider context, as they throw light on the distinct social relations and goals hidden behind socialisation activities. It is possible to reveal such experiences by referring to the time perspective and retaining distance.

Methodology of the research. The methodological convention of conducted reconstruction of experiences corresponds with the paradigm of biography research. Theodor Schülze considered various conventions of biography research, including:

a) biography understood as a text written by a person, or about such person written by someone else,

b) biography interpreted as a human life engaging analysis of the lifeline, personal experiences and social context of the life course,

c) biography that constitutes the process of shaping human's identity,

d) biography that results from typical or specific experiences of a given social group,

e) biography as a communicative function regarding human (Schültze, 1999).

Accomplishing the goals of research, the interviews were conducted within biography-oriented narrative framework. The explored part of the reality tackled personal experiences from the period of childhood and youth that the respondents interpreted as their socialisation and upbringing phase. For this purpose an open structure of the interviews was set up, in accordance with the interviews methodology by Fritz Schütze (Jemielniak, 2012).

The questions to the respondents explored the description of their childhood and youth, whereas the responses were methodically worked out afterwards. Therefore, partly ordered matrix of presentation of qualitative research was applied (Miles, Huberman, 2000) with two criteria of selection of the information on socialisation, i.e. actions of the participants of such process and knowledge regarding the remembered events.

The respondents group embraced 5 persons sentenced by the Polish penal authorities for criminal offences. Two Russians, one Ukrainian, one Belarusian and one Armenian are currently serving the sentence of deprivation of liberty in Polish prisons.

Social context of socialisation. The picture of social circumstances of socialisation regarding the researched respondents was interpreted in a wider context, as pedagogical literature often indicates, that the processes and experiences grounded in the course of primary and then secondary socialisation, as well as during the process of upbringing, intersperse and influence each other. From the perspective of current theoretical knowledge, it should be acknowledged that the course of human's socialisation requires engagement of both primary as well as secondary environments, hence apart from the family circles, it must embrace external subjects too (Łobocki, 2003). As far as academic 
reflections are concerned, there are no premises to classify such participants of socialisation, as the biographical research pays greater attention to the reconstruction of the role that the researched played for given persons.

Crucial information is rather provided by the fact how they remembered influences of various subjects and how it was assessed, not classified. Accomplishing the first assumption, the table 1 provides selected information depicting participants of socialisation as well as their activities.

Table 1. Socialisation experiences structured according to the participants of this process

\begin{tabular}{|c|c|c|c|c|c|}
\hline & $\begin{array}{l}\text { Case } 1 \text { - } \\
\text { 43-year-old } \\
\text { Armenian }\end{array}$ & $\begin{array}{l}\text { Case 2 - } \\
\text { 44-year-old } \\
\text { Russian }\end{array}$ & $\begin{array}{l}\text { Case 3- } \\
\text { 45-year-old } \\
\text { Russian }\end{array}$ & $\begin{array}{l}\text { Case } 4 \text { - } \\
\text { 38-year-old } \\
\text { Ukrainian }\end{array}$ & $\begin{array}{l}\text { Case } 5 \text { - } \\
\text { 36-year-old } \\
\text { Belarusian }\end{array}$ \\
\hline Parents & $\begin{array}{l}\text { - I didn't have } \\
\text { contact with } \\
\text { them } \\
\text { - I spent little } \\
\text { time at home } \\
\text { - I spent only } \\
\text { some short } \\
\text { time during } \\
\text { Christmas at } \\
\text { home, }\end{array}$ & $\begin{array}{l}\text { - they had to } \\
\text { cut off from the } \\
\text { church as it was } \\
\text { troublesome } \\
\text { - they didn't te- } \\
\text { ach me Russian } \\
\text { traditions }\end{array}$ & $\begin{array}{l}\text { - they liked folk } \\
\text { songs and were } \\
\text { hospitable } \\
\text { - I never spoke to } \\
\text { them about the } \\
\text { church, I wasn't } \\
\text { mature enough } \\
\text { for that }\end{array}$ & $\begin{array}{l}\text { - my mother } \\
\text { brought me up } \\
\text { alone and died } \\
\text { quickly } \\
\text { - I often met } \\
\text { with the sibling } \\
\text { and respected } \\
\text { family traditions }\end{array}$ & $\begin{array}{l}\text { my mother } \\
\text { brought me up } \\
\text { alone }\end{array}$ \\
\hline $\begin{array}{l}\text { Grandpa- } \\
\text { rents }\end{array}$ & & $\begin{array}{l}\text { - my grandmo- } \\
\text { ther had an icon } \\
\text { and sometimes } \\
\text { spoke of reli- } \\
\text { gion }\end{array}$ & $\begin{array}{l}\text { - my grandmother } \\
\text { sometimes prayed, } \\
\text { but our religious- } \\
\text { ness was neutral }\end{array}$ & & $\begin{array}{l}\text { - my grandfather } \\
\text { was Russian, I } \\
\text { have his Russian } \\
\text { citizenship } \\
\text { - my grandmo- } \\
\text { ther would } \\
\text { sometimes take } \\
\text { me to the church } \\
\text { where I was } \\
\text { bored }\end{array}$ \\
\hline Teacher & $\begin{array}{l}\text { - I learnt during } \\
\text { sports camps, } \\
\text { out of the family } \\
\text { circle }\end{array}$ & $\begin{array}{l}\text { - the teacher } \\
\text { was making } \\
\text { sure at the bus } \\
\text { stop during re- } \\
\text { ligious holidays } \\
\text { that we wouldn't } \\
\text { go to church }\end{array}$ & & $\begin{array}{l}\text { - I finished my } \\
\text { school, then } \\
\text { studies and after } \\
\text { serving in the } \\
\text { army I found } \\
\text { job far behind } \\
\text { Moscow }\end{array}$ & $\begin{array}{l}\text { - there were some } \\
\text { classes about Be- } \\
\text { larusian writers }\end{array}$ \\
\hline
\end{tabular}




\begin{tabular}{|c|c|c|c|c|c|}
\hline Priest & & $\begin{array}{l}\text { - I had no } \\
\text { contact }\end{array}$ & $\begin{array}{l}\text { - I didn't go to the } \\
\text { church, if it wasn't } \\
\text { for the prison, I } \\
\text { don't think I'd be } \\
\text { mature enough }\end{array}$ & $\begin{array}{l}\text { - we would often } \\
\text { go the church }\end{array}$ & \\
\hline Coach & $\begin{array}{l}\text { - more impor- } \\
\text { tant than my } \\
\text { father } \\
\text { - I was going for } \\
\text { sports camps all } \\
\text { the time }\end{array}$ & & & & \\
\hline $\begin{array}{l}\text { Other } \\
\text { persons }\end{array}$ & & $\begin{array}{l}\text { - Tatars lived } \\
\text { with us, we were } \\
\text { visiting them } \\
\text { during their } \\
\text { holidays }\end{array}$ & & $\begin{array}{l}\text { I live nearby } \\
\text { Lvov, we often } \\
\text { had contacts } \\
\text { with the Poles } \\
\text { so I speak Polish } \\
\text { well and I wor- } \\
\text { ked here for } 13 \\
\text { years }\end{array}$ & $\begin{array}{l}\text { - I wanted to be } \\
\text { with my friends } \\
\text { as a young man }\end{array}$ \\
\hline
\end{tabular}

The relation between the description of the younger and older respondents is very interesting, as those over 40 described their childhood from the 1970s, reflecting emphasis on the participation of the system authorities in shaping the young generation. External interference is intriguing, as it enhances taking responsibility for own child - for instance, the 43-year-old Armenian stressed that his childhood took basically place out of the family. He was meant to be prepared for the role of a sportsman, hence training and participation in acrobatic camps made him indirectly "taken away" from the family, who agreed for it to happen, considering their son's situation as fortunate, ensuring good prosperity in the future. Unfortunately, because of his injury the sports career collapsed and the future life ceased to be connected with sport. The acrobatics coach literally overtook the basic socialisation and upbringing functions, as the respondent himself claimed the coach to be more important in his life that the relatives. Similarly active functions were assigned to the teachers by the interviewed Russians (44- and 45-year-old), who perceived their actions as for the sake of secularisation of the young generation. As one of them said, the teachers made sure pupils would come back straight home from school, instead of visiting the church, hence were functioning as a party's clerk carrying out given vision of the system, whereas parents "had to cut off from the family" in order to avoid problems and conflicts with the representatives of the system. This article is not of historical character, hence the assessment of historical truth of these recollections is not 
a subject of exploration, but the change in perception of the system between the older and younger respondents is significant.

The younger respondents, i.e. over 30, experienced their childhood in the 1980s and refer to this period of individual development differently, as for instance, the role of a clerk-teacher that is engaged in the socialisation process did not exist any longer. Moreover, younger respondents did not indicate undercover conflict in terms of religious freedom, where the grandparents preserved religious contents instead of the parents, who were forced to follow the party's line. However, such situation implies another picture of socialisation of this generation, as disappearance of the system representatives or weakening their influence did not bring about introduction of new participants of the socialisation. None of the researched indicated palpable change of the influential mode towards the family or children. The modified picture of socialisation removed the active clerk and did not provide anyone or anything else in return. Therefore, it is worth to ask the question whether families left in such position could have carried out the process of socialisation better, taking advantage of the fact that the power of the system interference is weakened. Unfortunately, in case of the researched respondents such assumption was not confirmed.

Retrospection of the socialisation effects. Retrospection is of paramount importance while researching biographies, as it provides the attempt to examine different phenomena from the time perspective. While conducting research with the prisoners their answers refer not only to the memories, but also current situation, which in their case is unusual as they were influenced by the social reality and a system that no longer exists, and their examination of socialisation effects is specific. In order to present personal experiences and retrospection the table below provides comparison of the memories description from their childhood and a retrospective reflection.

It is worth to emphasise, that the respondents freely talked about their childhood, as they could say what they remember. They were not asked to assess the political or social system of that time, but rather spoke on their environment, where processes significant for the socialisation took place, according to the pedagogical literature, i.e. it embraced internalisation of the standards and values, as well as conceptualisation of the social attitudes and roles.

Table 2. Comparison of the experiences of socialisation and contemporary retrospection

\begin{tabular}{|l|l|l|l|l|c|}
\hline & Case 1- & Case 2- & Case 3- & Case 4- & Case 5- \\
43-year-old & 44-year-old & 45 -year-old & 38-year-old & 36-year-old \\
Armenian & Russian & Russian & Ukrainian & Belarusian \\
& & & & \\
\hline
\end{tabular}




\begin{tabular}{|c|c|c|c|c|c|}
\hline $\begin{array}{l}\text { What have } \\
\text { you learnt } \\
\text { about the } \\
\text { social surro- } \\
\text { unding? }\end{array}$ & \begin{tabular}{|l|} 
- I don't know \\
the Armenian \\
history, it ne- \\
ver interested \\
me \\
- I rarely spent \\
time at home \\
during religio- \\
us holidays \\
- we celebrated \\
some major \\
holidays \\
- I was injured \\
and couldn't \\
continue \\
trainings
\end{tabular} & $\begin{array}{l}\text { - parents cut off } \\
\text { from the church } \\
\text { as they had } \\
\text { to, in order to } \\
\text { avoid problems } \\
\text { at work } \\
\text { - I liked the } \\
\text { bank holidays, } \\
\text { for families } \\
\text { and children, } \\
\text { celebrated at } \\
\text { school } \\
\text { - we celebrated } \\
\text { religious holi- } \\
\text { days at home } \\
\text { - we used to go } \\
\text { to watch Tatars' } \\
\text { holidays, dance } \\
\text { at their perfor- } \\
\text { mances } \\
\text { - children from } \\
\text { the minority } \\
\text { had to learn } \\
\text { longer at school } \\
\text {,but there were } \\
\text { no conflicts }\end{array}$ & $\begin{array}{l}\text { - parents taught } \\
\text { me folk songs and } \\
\text { often met with } \\
\text { friends } \\
\text { - we weren't inte- } \\
\text { rested in Russian } \\
\text { culture } \\
\text { - I wasn't mature } \\
\text { enough to speak } \\
\text { with parents about } \\
\text { religion, it wasn't } \\
\text { a good thing to do } \\
\text { in communism } \\
\text { - life means to } \\
\text { work for money, } \\
\text { there was no time } \\
\text { for other things }\end{array}$ & $\begin{array}{l}\text { - we paid a lot of } \\
\text { attention to the } \\
\text { family traditions } \\
\text { - I'm not a crimi- } \\
\text { nal, I didn't pay } \\
\text { the fine so I had } \\
\text { to serve a short } \\
\text { sentence now }\end{array}$ & $\begin{array}{l}\text { - I didn't know } \\
\text { Belarusian } \\
\text { culture, there } \\
\text { was something } \\
\text { about Belaru- } \\
\text { sian writers } \\
\text { and books at } \\
\text { school, but I'm } \\
\text { not sure } \\
\text { - my grandmo- } \\
\text { ther someti- } \\
\text { mes took me } \\
\text { to the church } \\
\text { but I didn't } \\
\text { care } \\
\text { - Belarusians } \\
\text { are sociable } \\
\text { and like to } \\
\text { have fun }\end{array}$ \\
\hline $\begin{array}{l}\text { How do you } \\
\text { currently } \\
\text { evaluate own } \\
\text { experiences? }\end{array}$ & $\begin{array}{l}\text { - I'm not inte- } \\
\text { rested in my } \\
\text { country and } \\
\text { its history } \\
\text { - I just want } \\
\text { to leave the } \\
\text { prison }\end{array}$ & $\begin{array}{l}\text { - I take active } \\
\text { part in me- } \\
\text { etings with } \\
\text { Orthodox priest, } \\
\text { because if you } \\
\text { believe, there } \\
\text { are other values } \\
\text { out there } \\
\text { - I learn about } \\
\text { different ho- } \\
\text { lidays, now I } \\
\text { understand why } \\
\text { they exist at all } \\
\text { - I don't know } \\
\text { Russian tradi- } \\
\text { tions, but it's } \\
\text { interesting }\end{array}$ & $\begin{array}{l}\text { - now I find religi- } \\
\text { on interesting } \\
\text { - I watched the } \\
\text { believers and } \\
\text { noticed they feel } \\
\text { comforted } \\
\text { - if I wasn't in pri- } \\
\text { son I don't think } \\
\text { the religion would } \\
\text { draw my interest } \\
\text { as I didn't need it } \\
\text { for } 30 \text { years }\end{array}$ & $\begin{array}{l}\text { - I want to come } \\
\text { back to work } \\
\text { - I provide for } \\
\text { the entire family, } \\
\text { as in Ukraine } \\
\text { none of them has } \\
\text { permanent job }\end{array}$ & $\begin{array}{l}\text { - I attend } \\
\text { meetings with } \\
\text { prison priest, } \\
\text { as it calms me } \\
\text { down } \\
\text { - holidays in } \\
\text { prison is so- } \\
\text { mething new } \\
\text { - I'm not } \\
\text { interested in } \\
\text { Belorussia, I } \\
\text { just want to } \\
\text { leave prison, } \\
\text { that's all }\end{array}$ \\
\hline
\end{tabular}


The presented picture of own childhood and socialisation was predominantly related to the pragmatism of everyday life, as in all cases socialisation was limited to basic functions of recognising own social surrounding and principles that exists there. It served as a tool of adapting to the roles required in such surrounding, whereas personal experiences were mainly related to the essential knowledge, useful in everyday life. Unfortunately, the researched did not recall any events or experiences that would reach beyond the pragmatic dimension. It is difficult to find information on universal, historical or religious values in their experiences, that would prove to be a part of the effects of socialisation or upbringing. Hence, the interpretation of their social attitudes, referring to autotelic values is hindered. Such conclusion is confirmed by the retrospective assessment of the upbringing and socialisation effects from the childhood. Contemporarily, as adults, the researched do not posses knowledge regarding the culture of their country or its history. Regrettably, personal needs for such knowledge are insignificant and sporadic. Only two respondents paid more attention to these issues (both Russians), what could result from higher level of their education. They expressed lack of universal values in their lives and experiences moving beyond duties, work or entertainment, as before imprisonment only these aspect of life had drawn their interest. In their opinion such reflection resulted from greater maturity that came with time, but also from the imprisonment, which made them think their lives over. On the other hand, the Ukrainian citizen (38-year-old), also with higher education, underlined other experiences of family traditions or religious activities. During his imprisonment he does not focus on searching for new religious experiences, but wants to return quickly to work and assimilate with Polish society. Such stand resulted mainly from his specific biography, as he was sentenced to imprisonment for six months due to unpaid fine, hence - comparing to other inmates - it was a "temporary" sentence, and it did not make him think of his life or search for something timeless, that he could lack. Unfortunately the rest of the researched does not notice the need to search for something more permanent in their lives and their interests are limited to fulfilling everyday tasks. During the imprisonment they do not undertake attempts to evaluate their set of values, not try to expand it. Even if such opportunities occur during religious meetings, they consider it pragmatically as an opportunity to have some free time and meet with others.

Pragmatic and universal dimension of socialisation. The focus of these reflection is on the assessment of experiences recalled by each of the respondents. Their socialisation was shaped by the nearest environment, although in some cases party's clerks also participated in this process. However, the issue is not to assess the socialisation, but rather to confront personal experiences with theoretical picture of socialisation. At the level of pedagogical knowledge socialisation reaches beyond pragmatism of everyday life, leading towards mature upbringing and there are no distinct borders between these processes, as personal, spiritual or patriotic growth is joined and combined within one structure. 
Sadly, the described experiences of the researched are far from these assumptions, as their experiences terminated at the stage of folk knowledge regarding own nation and clear description of social roles, omitting all that moves beyond the prose of everyday life. It is hard to find in their recollections any accent put on timeless values, as they do not appear within the religious or national sense of belonging. Unfortunately some of the respondents, despite the passage of time or social or personal maturity, still do not experience lack of these values in their biographies.

The period of imprisonment is of paramount importance, as the respondents remain cut off from their ordinary activities, i.e. work and entertainment. They do not participate in the reality they were socialised to, hence their life situation - particularly passiveness of the imprisoned reality - may force them to search for something new. Paradoxically, it is the time to think over own life and behaviour, hence it can imply the perception of some lack in their lives. Even if such reflection is unaware, the experience of such lack could occur, caused by deprivation of timeless values or more complex set of values. Still, many of them do not even notice that such knowledge and values reaching beyond entertainment is needed in their lives.

The researched found themselves in a difficult position as the world they were accustomed to during socialisation does not exist anymore, as the Soviet Union is no longer their homeland, replaced by strong national and independent tendencies. Therefore, the emergence of more complex and widely discussed question within intercultural education is noticeable, namely, the difficulty of shaping sense of national belonging among those, whose socialisation is deprived of universal values. Such persons do not have their grounded sense of cultural identity or national tradition, fulfilling this niche with lucidity, that substitutes their process of establishing national identity. Hence, they do not describe their nation from the perspective of historical, cultural or religious difference, but perceive it as sociable, folk, open towards others. None of the respondents - particularly the citizens of Ukraine, Belorussia or Armenia - searches for the knowledge regarding their nation, and the process of establishing national identity takes place beyond their aware participation. Nonetheless, they recognise their belonging applying the attribute of citizenship and passport, with no consideration for the over-pragmatic values.

Although the nature of the research focuses on pedagogical dimension of understanding socialisation and its character, it also provides another conclusions, as it is worth to pay attention to the recognition of contemporary tendency to perceive socialisation, where the pragmatism of everyday life, work, and entertainment eliminate universal values. The period of Soviet Union and its system passed by, and after serving the sentence the prisoners will not return to that time reality and social relations. Still, the influences of that system are still strong, especially that they were stigmatised by marginalization of the sense of national diversity, eliminating religion and replacing it with folk entertainment and bank holidays, for the sake of "forced community". Notwithstanding, the impact of these influences appear significant despite the passage of time, as in the minds of many 
people, universal, autotelic values may as well not exist. Unfortunately, as the respondents prove, the problem lies not only in the lack of knowledge regarding universal values, but in the lack of any reflection or consideration for this issue, hence it is not searched for, not its absence is bothersome.

Notwithstanding, focusing on the described personal experiences there is an interesting issue revealed, i.e. socialisation of the new generations, as contemporarily many societies within European Union have to face the issue of historical and traditional transmission with tasks assigned to the process of socialisation. The role of the family, school and mass media in the growing social sphere is also a subject of discussions. Hence, within these reflections it is worth to ponder over the question regarding the direction and sense of socialisation, i.e. whether it should serve the pragmatism of everyday life and the social assimilation, or quite the contrary. In this case, the research among citizens of former Soviet Union provide many reflections, as it sets an example of phenomenological values of qualitative research, where personal stories introduce the researcher to a wider context of social issue, including socialisation. The research embraces not only the area of experiences, but also far-reaching effects of the socialisation of the generation deprived of universal values exploration, where autotelic meaning was overcome by the pragmatism of everyday life.

\section{References}

Jemielniak, D. (2012). Badania jakościowe. Metody inarzędzia. Tom 2 (pp. 98-103). Warszawa: Wydawnictwo Naukowe PWN.

Łobocki, M. (2003). Teoria wychowania w zarysie (pp. 32-48). Kraków: Impuls.

Miles, M. B., \& Huberman, A. M. (2000). Analiz adanychjakościowych (pp. 182-186). Białystok:

Trans Humana.

Schültze, T. (1999). Erziehungswissenschaftliche Biographieforschung: Anfange-FortschritteAusblicke. In H. H. Kruger, \& W. Marotzki (Eds.). Handbucherziehungswissenschaftliche Biographieforschung (pp. 39-40). Opladen: Leske+Budrich. 


\title{
Socializacijos pragmatinè ir universalioji dimensijos kaliniu (buvusio socialistinio bloko šalių piliečių) patirties aspektu
}

\author{
Arkadiusz Urbanek \\ Vroclavo universitetas, Istorijos ir pedagogikos katedra, Pedagogikos institutas, \\ J. W. Dawida g. 1, 50-527 Vroclavas, Lenkija, urbanek.akradiusz@vp.pl
}

\section{Santrauka}

Straipsnyje nagrinejami socializacijos ir ugdymo klausimai, remiantis buvusių socialistinio bloko šalių piliečių, dabar kalinčių šiandienès Lenkijos pataisos institucijose, patirtimi. Tyrimas pateikia vaikystès patirčių apibūdinimą pagal respondentų atsakymus ì du klausimus, atskleidžiančius respondentų pirminès ir antrinės socializacijos vaidmenị, iš vienos pusės, ir kaip toji patirties praeitis yra susijusi su dabarties refleksine patirtimi, iš kitos pusès. Šio kokybinio tyrimo rezultatų interpretacija socializaciją ir jos autotelinị, arba pragmatinị, tikslą leidžia laikyti atskaitos tašku. Remiantis respondentų apibūdinta asmenine patirtimi, straipsnyje daroma išvada, kad tiriamųjų ankstesniojo periodo socializacija ignoravo autotelinę socializacijos prigimtị ir vyravo vien pragmatiniai siekiai. Dabartiniu periodu, jau praejus nemažai laiko, tie asmenys sunkiai suvokia amžinųjų vertybių poreikị ir jų svarbą savo gyvenimui. Dauguma respondentų savo veiklos šiuo aspektu nereflektuoja ir nèra linkę užpildyti šios spragos.

Esminiai žodžiai: socializacija, asmeninè patirtis, biografija, vertybès ir socializacijos patirtis. 